\title{
Implementation of learning based on the 2013 curriculum
}

\author{
Maulidha *, Aslamiah, Nina Permata Sari \\ Master Program of Early Childhood Teacher Education, Universitas Lambung Mangkurat, Banjarmasin \\ 70123, Indonesia
}

\section{Article history: \\ Submission September 2020}

Revised December 2020

Accepted December 2020

*Corresponding author: E-mail:

maulidharifani@gmail.com

\begin{abstract}
At this time, private PAUD institutions became a special attraction because they were better known by the wider community with Islamic education and character, this condition was the main choice due to the success of managers and educators in implementing the curriculum. The research objective was to determine the planning, implementation of assessment as well as supporting and inhibiting factors in the implementation of curriculum 2013 learning. The research approach used was qualitative with the type of multisite study. The research instrument is the researcher himself. Collecting data using interviews, observation, and documentation with cross-site data analysis. The data were collected through interviews, observation, documentation, and then analyzed using Miles Huberman's data analysis theory techniques, namely data reduction, data presentation, and conclusion drawing. The results of the research on the implementation of curriculum learning carried out are (1) Planning that is prepared at the beginning of the school year through various coordination meeting activities, analysis of the completeness of supporting facilities, student conditions by integrating Islam, character, and local culture (2) Implementation of learning that has formed a drafting team and conduct training or monitoring carried out with learning strategies using the center and group method, as well as thematic learning and extracurricular programs that can develop children's abilities (3) Assessment is carried out by all interested following their duties. (4) the supporting and hindering factors as determinants are the completeness of the infrastructure and the lack of a variety of games prepared.
\end{abstract}

Keywords: Curriculum 2013, the implementation of learning

\section{Introduction}

Early Childhood Education (PAUD) is the most fundamental education because the development of children in the future will be largely determined by various meaningful stimulations given from an early age. Early childhood education does not refer to a single entity, rather, the term covers a variety of programs for young children between their early life and the age of eight years old (Bowman, 1993). During childhood, children can be seen as active learners, constructing their knowledge through interaction with their environment (Piaget, 1952). Children can make meaning from experience through social interaction, dialogue, and mutual adjustment with adults and other children as a foundation for learning (Rogoff, 1990). Meanwhile, the locus of children's upbringing is the family (Nawrotzki, 2009) and education. Hence, it is important to build a high-quality education system that starts at the age of three and extends through the third grade (McCarthy et al., 2011).

All of the children's early childhood education and their experiences is to achieve self-actualization in the later years of their life. Carl Rogers stated that the goal of life is to achieve self-actualization or have personality traits that make life the best (the good life). A fully functioning person is a term used by Rogers to describe an individual who uses his capacity and talent to realize his potential and moves towards a complete understanding of himself and his entire range of experience (Nurdin \& 
Sibaweh, 2015). Self-actualization can be considered a motive, striving, need, or goal which involving behaviors directed toward the fulfillment of personal potentials (Waterman, 2014). Meanwhile, realizing one's full potential is linked to the fundamental motive of achieving status and esteem (Krems et al., 2017). It is, for Goldstein (Whitehead, 2017), what has been called individuation, or a process of becoming a 'self' and acts as a primary driving force of behavior in humans. Self-actualization can be also seen as an openness that people can be not just self-actualizing, but also are very open (Mittleman, 1991). Meanwhile, the term of self-actualization is quite a definite and achievable level of consciousness (Rowan, 2015). Albert Ellis in Bernard, Froh, DiGiuseppe, Joycem \& Dryden (2010) has stated that self-actualization involves the pursuit of excellence and enjoyment; whichever people choose to desire and emphasize.

The self-actualization leading to becoming a fully functioning person. According to Socrates, each thing in this world has a function (Korsgaard, 2008). Aristotle (1996) then describes that the highest human good is "activity of the soul following virtue". The fully functioning person can be seen as he is in and of the society of which he is a member, but he is not a prisoner of that society (Hayakawa, 1956). The self has to be achieved, as it is not given, which consists, in part at least, of the accumulated experiential background of the individual that is built since the very first time the life is begun (Kelley, 1967). To be fully functioning, Keyes (2002) has explained that individuals must be social well-being. Also, some psychological needs must be satisfied for humans to function optimally. All of these are what children need the most to be able to achieve their self-actualization and can become a fully functioning person. However, people perceive their inner and outer environments imperfectly, including children of early age. Thus, education is very important to guide them in the right direction.

The national education system, in general, has guaranteed educational opportunities throughout the nation, the quality of improvement and the relevance and efficiency of education to face current challenges and changes in life at the local, national and global levels. The use of the term national system can be seen as the voicing of actors and the territorial coverage on institutional mechanisms of educational management (Duarte \& Dos Santos, 2017). Within the national education system usually, there is a compulsory education which refers to the period seen being the most crucial for children between certain ages in a certain country to get formal education getting required by law. According to Sterman (2000), education is considered to be a complex system. The complexity of education including education as an interconnected system, education within a system of systems, education is history-dependent, and education as a non-linear system (Ghaffarzadegan et al., 2017).

The stratified education systems educate students more efficiently in overall levels of competence (Sporlein \& Schlueter, 2018). Therefore, it is necessary to reform education that is planned, directed, and sustainable (Sukriani, Huda A.Y, Arifin, \& Suriansyah, 2017). As in Indonesia, the biggest challenge regarding education is no longer improving access but improving quality (Rosser, 2018; Dalle \& Mutalib, 2018).

The national education system, in general, has guaranteed educational opportunities throughout the nation, the quality of improvement, and the relevance and efficiency of education to face current challenges and changes in life at the local, national and global levels. Therefore, it is necessary to reform education that is planned, directed, and sustainable (Machali, 2014). Education reform projects are usually designed to bring about major improvements in school and value student outcomes (Airini, McNaughton, Langley, \& Sauni, 2007). During the process, education reform needs the involvement of students in all aspects to get succeeded and proceeded (Levin, 2000); (Taines, 2012). The education reform can be the effect of changing the environment (Cohen et al. (2017) which urging the changes in education as well to attain a better future generation. However, relying solely on school management to develop a new culture cannot produce optimal results without the involvement of teachers. This is because teachers have the 
autonomy to make changes in their daily practices in the teaching and learning process in the classroom (Lee et al., 2018).

A child in early childhood is a researcher (Malone, 2013). All forms of curiosity always want to be answered and proven (Krapp \& Prenzel, 2011). It is because it has become one of the characteristics of early childhood, namely, high curiosity (Purwanti et al., 2018). So, it is not surprising if they are happy to try new things at an early age or do trials of new things that they have never known. During this time, Social and emotional skills begin to develop such as self-confidence and other competencies in building relationships, solving problems, and coping with various emotions (Parlakian, 2003). Academic achievement is predicted to get influenced by social and emotional competencies owned by the children. Children with greater self-control or self-regulation will be growing into adults with better health, have higher incomes, fewer financial struggles, and fewer criminal convictions compared to those whose self-regulatory skills are weak.

The golden age is a period where children begin to be able to accept and respond to various stimuli from their environment, whether they are intentional or not. By this time the child's physical and psychological functions are mature, enabling them to respond to and complete all developmental tasks that are expected to appear in their daily behavior. Not only one aspect of development can develop optimally, but all aspects of child development such as language, cognitive, social-emotional, physical motoric, and religious and moral values can all develop optimally. Therefore, the learning process for the 2013 Curriculum is following Government Regulation Number 32 of 2013 concerning amendments to Government Regulation number 19 of 2005 concerning National Education standards, basically strengthening the previous curriculum and developing aspects of the curriculum structure.

The curriculum is an instructional design that summarizes all the learning experiences provided for students at school. According to Taba, the curriculum can be viewed as a list of courses or lesson plans (van den Akker, 2004). In philosophy, curriculum, values, knowledge must be integrated with educational actions (Suhaimi \& Rinawati, 2018). The curriculum needs to pay more attention to the process than to results as well as provide opportunities for students to innovate (Bron et al., 2016). Thus, focusing on the understanding of curriculum theory and assumptions about students will increase understanding of curriculum objectives (Bovill \& Woolmer, 2019). Every curriculum that is designed must reflect the vision, mission, and goals of the school. The curriculum is also important to innovate, update, and develop the previous curriculum to be even better in the future (Andriyani et al., 2018). Because success in achieving educational goals is determined by the foundation in learning and the elements in it, namely students, educators, student and educator interactions, environment, material/educational content (Salasiah et al., 2018).

The 2013 curriculum is the result of refining the previous curriculum, namely KTSP 2006. KTSP is implemented to empower regions and schools in planning, implementing, managing, and assessing learning according to conditions and aspirations. In the implementation of this curriculum, there were many problems, both from human resources, unsupportive infrastructure suggestions, therefore the 2013 curriculum was created as a change from the KTSP curriculum structure. The PAUD curriculum with its main thematic-integrative characteristics is used as the basis for curriculum changes at a higher level, so that the PAUD curriculum has been seen as still relevant to the times, especially meaningful learning for students (Suyadi \& Dahlia, Implementasi dan Inovasi Kurikulum 2013, 2017).

The implementation of the 2013 curriculum policy for early childhood education as stipulated by the Minister of Education and Culture Decree Number 146 of 2014 concerning the 2013 Curriculum for Early Childhood Education. Along with the implementation of the 2013 PAUD curriculum, the Minister of Education and Culture Regulation Number 137 of 2014 was issued which regulates the National Standard for Early Childhood Education. The policies in the two laws have implications for the development of the Education Unit Level 
Curriculum (KTSP PAUD) which must be developed by each PAUD level Education Unit. The two regulations contain the idea of the 2013 curriculum so that both should be understood by the PAUD-level KTSP development team. As stated by (Hasan, 2008) that curriculum ideas are the most important component in the curriculum development process.

Curriculum ideas are the most important component in the curriculum development process which is a formulation of the philosophical position of education adopted, theoretical views on curriculum concepts, the curriculum model used, the concept of content, curriculum organization, curriculum design, curriculum document design, the position of students in learning. Curriculum ideas must be clear because these ideas form the basis and foundation for the development of various components of the curriculum document. This opinion shows that in curriculum development, curriculum ideas need to be understood by the development team so that the development of curriculum documents that are prepared reflects continuity with curriculum ideas. Without clarity of curriculum ideas, it is possible to have a discontinuity between the idea and the curriculum document.

According to Rozalena and Kristiawan, in realizing PAUD which can develop early childhood potential, it is necessary to have Planning (planning), Organizing (organizing), Actuating (implementation), and also Controlling (controlling) which is then abbreviated as POAC. Without POAC, PAUD learning will not run effectively and efficiently in achieving its goals (Rozalena \& Kristiawan, 2017).

Kindergarten education is a form of early childhood education that has an important role in developing children's personalities and preparing them to enter the next level of education (Suriansyah \& Aslamiah, 2011). Each child is unique, whether due to genetic or environmental factors. Which is very influential in the way children learn. Seeing this, PAUD institutions must also have an adequate curriculum structure to facilitate their students. Fundamentally, the 2013 Curriculum for Early Childhood Education is expected to be the basis for the preparation of students to be more confident in moving to a higher level of education.
The 2013 Curriculum for Early Childhood Education is developed inclusively to provide the basis for the formation of mutual respect and non-discrimination which is developed following the demands and norms prevailing in the local community. In an education system, the curriculum is dynamic, and changes and developments must always be made, to keep up with the developments and challenges of the times, change and development must be carried out systematically and directed. Changes and curriculum development must have a clear vision and direction (Mulyasa, 2016).

Seeing the importance of implementing teaching following the relevant curriculum for local conditions, it is important to examine more deeply the implementation of learning following the stages of child development and the 2013 PAUD curriculum. Early Childhood Core Competencies as an application of the 2013 Early Childhood Education curriculum not all PAUD institutions have implemented it. Changes in the curriculum to date are still marked as changes in curriculum documents, but the way teachers teach has not changed so that it will have an impact on the level of achievement of children's development that has not reached the standard level of achievement of child development.

The teacher's role also does not have to be from the success of learning. The teacher as the spearhead of learning, choosing capital, learning strategies is quite good for learning success. The teacher's role is to help children gain the ability to communicate, solve problems, and resolve conflicts. Activities can be planned specifically to promote cooperative behavior in the classroom and learning centers for kindergarten children, cooperative learning can make them more creative (Suriansyah, 2011).

According to Baiti, Metroyadi, \& Wahyu (2019) The role of teachers and parents is very important in children's development, especially in understanding the golden age of children as early as possible. When conducting this research, the teacher found many benefits, including the teacher being able to understand that the child will be more active when the child is directly involved in these activities, the use of interesting media will foster children's attention, by directly training the child. get their own 
experience, being a teacher does not only tell the activity but the children do it immediately so that the cultivation of the independent attitude that the teacher wants to achieve can run optimally.

The teacher develops learning to increase children's success by using the learning principles stated by Suriansyah \& Aslamiah (2011) that learning is done concretely and it can be seen that the child is recognition, physically and mentally balanced. The research objective is to identify and describe. Planning, implementation, assessment, supporting, and inhibiting factors for the implementation of learning based on the 2013 PAUD curriculum. The purpose of this study is to determine the planning, implementation of assessment, and supporting and inhibiting factors in the implementation of the 2013 curriculum learning.

\section{Material and Methods}

This study used a qualitative descriptive approach with a multi-site research design and data collection techniques through interviews, observation, and documentation. Research time for one year. Data were analyzed from the research process in the field that was carried out until the end of data collection using data analysis techniques proposed namely data reduction, data presentation, and conclusion drawing.

The objects of observation consist of educators, educational staff, and learning activities. The object of the interview is related to how to plan, implement, evaluate, support, and inhibit the implementation of learning based on the 2013 PAUD curriculum. Observations were made directly by observing the learning process in PAUD Sang Leader and PAUD IT Nurul Fikri Banjarmasin City with learning activities including facilities and infrastructure owned.

Furthermore, how the Weekly Learning Implementation Plan (RPPM), (daily learning implementation plan) RPPH, Standard Operating Procedures (SOP), institutional profile, vision, mission, institutional objectives, administrative structure, photos of activities, and other books are used to support the 2013 PAUD curriculum this part contains the methods, data, source of data, data collecting technique, and data analysis technique.

\section{Results and Discussion}

A curriculum is a place that will determine the direction of education, success, or failure of education depending on the curriculum used. The 2013 curriculum is a new curriculum applied in the 2014/2015 school year. The focal point in the 2013 curriculum is an increase and balance such as competency attitudes, skills, and knowledge. The goals and functions of the 2013 curriculum lead to law no. 20 of 2004 concerning the National education system. In the National Education System law, it is explained that the function of the curriculum is to increase the ability and form of thought as well as a dignified national civilization to educate the nation's life. The curriculum is a set of plans and arrangements regarding the objectives, content, and learning materials as well as the methods used as guidelines for implementing learning activities to achieve certain educational goals. The curriculum is all school efforts to influence students to learn, both in the classroom and outside of school. Meanwhile, the curriculum is all activities given to students under school responsibility (all of the activities that are provided for the students by the school). The curriculum is a cooperative, comprehensive, systematic curriculum management system to achieve goal achievement (Rusman, 2012).

According to Suparlan (2013), four curriculum functions. namely: (1) Planning. If it fails to plan, it will fail the implementation of other functions. Benjamin Franklin stated ("By failing to prepare, you are preparing to fail"). Peter Drucker reminded that "planning is an unending course of action" or planning is an endless activity stage; (2) Organizing or organizing is also known as "the subsequent function" or a subsequent function. (3) Direction or directing. Its function is to control and supervise the activities of all staff or stakeholders, including providing assistance and technical guidance to all staff. A productive organization must be able to build a productive work environment, positive interpersonal relationships, and a wise 
problem-solving process if an organization encounters obstacles and problems; (4) Control (Control) such as establishing organizational work standards, namely achievement standards set based on organizational goals. Included in the control function is conducting regular evaluations and reporting to school stakeholders.

\section{Planning}

Curriculum planning is the planning of learning opportunities that are intended to foster students towards the desired behavior change and assess the extent to which changes have occurred in students. According to Hamalik (2005), curriculum planning is a complex social process according to various types and levels of decision making. Besides that, according to Rusman (2012), curriculum planning also serves as a driving force for implementing the education system to achieve optimal results. According to Prastowo, learning planning has at least eight functions, including selective functions, communicative functions, predictable functions, accuracy functions, goal achievement functions, and control functions. According to Rusman (2012), several bases for curriculum planning; a) Social Strength, b) Knowledge Treatment, c) Human Growth and Development.

When making learning planning, educators need to consider (1) who is involved, (2) how the learning style is, (3) when it is carried out, (4) in what events will learn occur, (5) where the learning events will occur. takes place, (6) how much learning time will be used (7) what resources and tools will be used (8) and how to assess the success of students. In planning the 2013 curriculum learning program at school, several stages are in its development, namely: a) Syllabus development, b) Semester programs, c) Weekly and daily lesson plans. According to Hasan $(2008$, p. 123) the clarity of curriculum ideas is very helpful for the development team in constructing curriculum documents

According to (Suyadi, Management of PAUD TPA-KB-TK / RA, 2011) Children's learning is adjusted to the level of children's development which includes language skills, thinking power, creativity, and physical skills or dexterity. So that all levels of child development can be accommodated in learning activities, learning is mapped into themes and time allocations effectively and efficiently.

\section{Implementation}

Several factors influence curriculum implementation, namely curriculum characteristics, assessment characteristics implementation strategies, teacher knowledge about the curriculum, attitudes towards the curriculum, and directing skills. The implementation of the curriculum involves many factors such as attitudes, mindsets, perceptions, philosophical assumptions, feelings of teachers and teacher groups as well as school culture consisting of parents, community, and government, is very strategic if continuous clarification of various aspects of changes will occur if the curriculum is carried out. Implemented (Afifah et al., 2019).

Meanwhile, according to Mars, five elements affect the implementation of the curriculum as follows (Rusman, 2012): support from the principal, support from peer teachers, support from students, support from parents, and support from within the teacher are the main elements. The implementation of the curriculum should place the development of student creativity beyond mastery of the material. Students are placed as subjects in the learning process, learning to think should be developed by emphasizing student activities to find solutions to objects, analyze, and construct so that they form new knowledge in students. Therefore, learning is not only transferring or providing information, but rather creating an environment that allows students to think critically and form knowledge.

To implement a curriculum according to the design, it takes some readiness, especially readiness for implementation, and depending on the teacher, the teacher is the main key to successful curriculum implementation (Rusman, 2012).

In the learning process, the learning model is very important to implement, according to Suyadi \& Dahlia (2017), the learning model is a systematic learning process design that includes learning approaches, learning strategies, learning methods, and learning techniques. 


\section{Assessment}

According to Mulyasa (2016), curriculum assessment must cover aspects of knowledge, skills, and attitudes as a whole and proportionally, following predetermined core competencies. Every teacher has beliefs and views on the curriculum and tests and reflects on the curriculum that includes planning, implementation, and evaluation. According to him, an educational assessment is a criterion.

According to Suyadi (2011), in the PAUD curriculum, evaluation guidelines contain a general explanation of evaluation activities that must be considered and implemented for PAUD administrators, including evaluation objectives, principles, and procedures. in making evaluation reports, to obtain more objective and accurate data.

According to Mulyasa (2016) (there are several components of the assessment carried out in learning, namely: 1) Observation, the assessment process can be done by observation (observation), and reflection. 2) Performance, in the 2013 curriculum assessment the teacher is highly recommended to prioritize performance assessment 3) Character assessment, character assessment is intended to detect the character formed in students through the learning that has been followed. 4) Portfolio assessment, is a collection of tasks performed by students, an assessment of all tasks performed by students in a particular lesson.

Another factor to support the development of children's learning outcomes is the ability of teachers to deliver learning material that motivates and can coordinate children in the class (Metroyadi \& Mardhiah, 2018).

Teachers as evaluators collect and analyze data through observation and interpretation is the main form of data collection and analysis in curriculum development. Assessing student learning outcomes needs to pay attention to the following points (1) the assessment measures the entire curriculum content, (2) the assessment is carried out rationally and efficiently, (3) the assessment that has been carried out has measured complex national and local standards in various works.

\section{Supporting and inhibiting factors}

In the national education strategy plan, there are at least five main problems whose solutions must be prioritized. These problems are related to improving the quality of education, improving the quality of education, increasing the efficiency of education management, increasing the relevance of education, equitable distribution of educational services, character education. (1) Efforts to improve the quality of education are carried out by setting goals and standards of educational competence, namely through a national consensus between the government and all levels of society, different competency standards between schools and between regions will produce national competency standards at the minimum, normal (mainstream) standard, and superior. (2) increasing the efficiency of education management leads to a competency-based and character-based curriculum structuring by giving broader trust to schools to optimize the available resources to achieve the expected educational goals, (3) increasing the relevance of education towards community-based education with a participatory approach (4) equitable distribution of education services leads to just education, this is related to the application of fair and transparent education financing formulas, efforts to equalize the quality of education with minimum competency standards and equal distribution of educational services for students at all levels of society, (5) character education to foster and develop philosophical values and develop the entire character of the nation in various types and levels of education as a whole and comprehensively (Mulyasa, 2016).

There are several important things from changes or improvements to the curriculum, namely the advantages and disadvantages that are here and there. There are several advantages and disadvantages in this form of curriculum, including the following:

a. This curriculum does not have a logical and systematic sequence.

b. Requires a lot of time and varies according to the needs of students and groups.

According to Mulyasa, the advantages of this curriculum are as follows: 
a. Study the lesson material through problem-solving.

b. Provide opportunities for students to learn according to their talents, interests, and potential.

c. Providing opportunities for students to solve problems comprehensively and be able to develop cooperative learning.

d. Practicing democratic values in learning.

e. Provide opportunities for students to learn optimally.

f. Provides students with learning based on direct experience.

g. Can help improve relationships between schools and communities.

h. Can eliminate the boundaries contained in other curriculum patterns. i. Can allow the abilities achieved by students to be strikingly different.

One of the factors that influence the success of implementing the 2013 curriculum learning is the teacher, the teacher occupies a central position because it's role is very decisive. The teacher must be able to translate and describe the values contained in the curriculum, then change these values to students through the learning process at school. The teacher does not create or compile a curriculum, but uses the curriculum, describes it, and implements it through a learning process.

The data obtained from the two institutions are compared in table 1 as follows:

Table 1. Comparison of findings from site 1 and site 2

$\begin{array}{llll}\text { No. } & \text { Research Focus } & \text { Data Of Site } 1 & \text { Data Of Site } 2\end{array}$

\begin{tabular}{|c|c|c|}
\hline 1. & $\begin{array}{l}\text { How to plan the im- } \\
\text { plementation of } \\
\text { learning based on the } \\
\text { curriculum } 2013 \\
\text { PAUD? }\end{array}$ & $\begin{array}{l}\text { a. Vision and mission (religius values, } \\
\text { character) } \\
\text { b. Educational calendar } \\
\text { c. Prota (Annual Program) } \\
\text { d. Theme } \\
\text { e. Prosem (semester program) } \\
\text { f. Determine the peak of the learning } \\
\text { theme } \\
\text { g. RPPM } \\
\text { h. RPPH }\end{array}$ \\
\hline 2. & $\begin{array}{l}\text { How is the imple- } \\
\text { mentation of learn- } \\
\text { ing based on the cur- } \\
\text { riculum } 2013 \text { PAUD? }\end{array}$ & $\begin{array}{l}\text { a. Group Learning, } \\
\text { b. } 8 \text { Beyond circle time for kindergar- } \\
\text { ten, namely role-playing centers, } \\
\text { preparation centers, natural materi- } \\
\text { als centers, blocks centers, art cen- } \\
\text { ters, imtaq centers, cooking centers, } \\
\text { body sports centers } \\
\text { c. Using learning media according to the } \\
\text { theme } \\
\text { d. Carry out the } 5 \mathrm{M} \text { learning stages as in } \\
\text { the } 2013 \text { curriculum (Observe, ask } \\
\text { questions, collect association infor- } \\
\text { mation and communicate }\end{array}$ \\
\hline
\end{tabular}

a. Vision and mission (religius values, character)

b. Educational calendar

c. Prota (Annual Program)

d. Indicator JSIT

e. Theme

f. Prosem (semester program)

g. Determine the peak of the learning theme

h. RPPM

i. $\mathrm{RPPH}$

a. Group Learning

b. 4 Beyond circle time s, natural materials, preparation, playing blocks, role-playing

c. WAFA Learning

d. Using learning media according to the theme

e. Observe, inquire, collect association information and communicate 


\begin{tabular}{|c|c|c|c|c|c|}
\hline 3. & $\begin{array}{l}\text { How are the results } \\
\text { of the implementa- } \\
\text { tion based on the } \\
\text { curriculum } 2013 \\
\text { PAUD? }\end{array}$ & & $\begin{array}{l}\text { Assessment using anecdotes, check- } \\
\text { lists, and works. } \\
\text { Daily assessment } \\
\text { Monthly } \\
\text { Semester } \\
\text { Reporting to parents every semester }\end{array}$ & $\begin{array}{l}\text { b. } \\
\text { c. } \\
\text { d. } \\
\text { e. }\end{array}$ & $\begin{array}{l}\text { Assessment using anecdotes, } \\
\text { checklists, and works. } \\
\text { Daily assessment } \\
\text { Monthly } \\
\text { Semester } \\
\text { Reporting to parents every day } \\
\text { and at the end of the semester }\end{array}$ \\
\hline 4. & $\begin{array}{l}\text { What are the sup- } \\
\text { porting and inhibit- } \\
\text { ing factors for imple- } \\
\text { menting a curricu- } \\
\text { lum based learning } \\
2013 \text { PAUD? }\end{array}$ & & $\begin{array}{l}\text { Supporting factors } \\
\text { 1) attention from schools that al- } \\
\text { ways develop teacher compe- } \\
\text { tence in exploring the talents and } \\
\text { abilities of teachers to be more } \\
\text { advanced and professional in } \\
\text { teaching } \\
\text { 2) hone skills by participating in } \\
\text { various competitions, training, } \\
\text { and seminars } \\
\text { Obstacle factor, teachers who have } \\
\text { not fully mastered IT }\end{array}$ & a. & $\begin{array}{l}\text { Supporting factors } \\
\text { Schools that always develop } \\
\text { teacher competence in exploring } \\
\text { the talents and abilities of teach- } \\
\text { ers to be more advanced and pro- } \\
\text { fessional in teaching. The school } \\
\text { always holds meetings and train- } \\
\text { ing for teachers once a month } \\
\text { Obstacle factor } \\
\text { As far as difficulty in developing } \\
\text { indicators becomes a playing ac- } \\
\text { tivity, because tools and materials } \\
\text { must be provided following the } \\
\text { existing theme so that teachers } \\
\text { are required to be creative in de- } \\
\text { veloping a variety of games and } \\
\text { also in the procurement and man- } \\
\text { ufacture of playing tools in learn- } \\
\text { ing }\end{array}$ \\
\hline
\end{tabular}

2. The process of implementing the curriculum is as much as possible according to

\section{Conclusion and Recommendation}

Based on the results of research and discussion of the implementation of curriculum 2013 learning in the Integrated PAUD Terpadu Sang Pemimpinand PAUD IT Nurul Fikri Banjarma$\sin$, the conclusions of the focus of the discussion are:

1. Curriculum planning is carried out to achieve the vision, mission, and objectives of the PAUD institution which is compiled by forming a team for curriculum compilers and makers, annual programs, semester programs, educational calendars, minimum completeness criteria, and RPPH carried out by the coordinator and each teacher, after the curriculum document is complete, it is submitted to related parties to obtain legality or validity from related parties as a tool to run the curriculum. the existing standards carried out by the teacher with learning strategies using the center and group method, as well as thematic learning and extracurricular programs that can develop children's abilities. The scientific approach to learning includes several aspects including (5) observing, asking, gathering information, reasoning, and communicating.

3. The assessment is carried out by the teacher who is in charge of supervising the educator, including anecdotes, checklists, and work, in addition to supporting tools for authentic assessment in the form of photos and videos which are carried out every day from the child coming to school to home, after which a monthly assessment recap is carried out, and semester, in the end, the assessment reporting is in the form of student report 
cards. As for delivering material to students, assessing the success of student learning can be carried out in two ways, namely formative evaluation, and summative evaluation.

4. Supporting and inhibiting factors

a. Supporting factors, namely (1) The procedure for the formation of the curriculum program structure is designed jointly and involves many parties. (2) facilities and infrastructure. (3) High teacher performance.

b. Inhibiting factors, namely learning facilities and infrastructure that are not evenly equipped

From the research results, it is suggested to make more varied playing activities and improve the quality of experts in information flogy and to increase the variety of play for children to achieve the vision, mission, and learning objectives in the specified curriculum. While for other things such as buildings, cleanliness, and others it is good in various ways.

\section{Acknowledgment}

Thanks to the head of the program, the secretariat, and the lecturers of the Master of Teacher Education Program in Early Childhood Education at Lambung Mangkurat University, Banjarmasin, who have provided input and suggestions for writing this article. Furthermore, thanks to the educators and education staff at PAUD Terpadu Sang Pemimpin dan PAUD IT Nurul Fikri Kota Banjarmasin, who have helped with the smooth running of this research. May we all always be in the Blessing of Allah SWT. Amen.

\section{References.}

Afifah. N, Suriansyah. A, \& Aslamiah. (2019). Implementation of Islamic Aqidah-Based Curriculum at Khoiru Ummah's Tahfizh Plus School. $j$-K6EM, 2, 47-57.

Airini, McNaughton, S., Langley, J., \& Sauni, P. (2007). What educational reform means: lessons from teachers, research and policy working together for student success. Educational Research for Policy and Practice 6, 31-54.

Andriyani, E., Ngadimun, \& Suriansyah, A. (2018). Character Education Management. IOSR Journal of Research \& Method in Education (IOSR-JRME), 8 (6), 13.

Aristotle. (1996). The Nicomachean ethics (trans: Ross, W. D.). Wordsworth Editions Limited. UK: Ware.
Baiti, N., Metroyadi, \& Wahyu. (2019). Pola Asuh, Sosial Ekonomi, dan Komunikasi Orang Tua Terhadap Kemampuan Bahasa Anak. j-K6EM, 2(1), 1-11.

Bernard, M., Froh, J., DiGiuseppe, R., Joyce, M., \& Dryden, W. (2010). Albert Ellis: Unsung hero of positive psychology. Journal of Positive Psychology, 5(4), 302-310.

Bovill, C., \& Woolmer, C. (2019). How conceptualisations of curriculum in higher education influence student-staff cocreation in and of the curriculum. High Educ 78, 407-422.

Bowman, B. (1993). Early Childhood Education. Review of Research in Education, 19, 101-134.

Bron, J., Bovill, C., \& Veugelers, W. (2016). Students experiencing and developing democratic citizenship through curriculum negotiation: the relevance of Garth Boomer's approach. Curriculum Perspectives, 36(1), 15-27.

Cohen, D. K., Spillane, J. P., \& Peurach, D. J. (2017). The Dilemmas of Educational Reform. Educational Researcher, Vol. 47(3) , 204-212.

Dalle, J., \& Mutalib, A. A. (2018). The impact of technologies in teaching interaction design. Journal of Advanced Research in Dynamical and Control Systems, 4(special issue), 17791783.

Duarte, M. R., \& Dos Santos, M. R. (2017). Brazil's national education system and how it was though. Rev. Bras. Educ. vol.22 no.71.

Ghaffarzadegan, N., Larson, R., \& Hawley, J. (2017). Education as a Complex System. Syst Res Behav Sci, 34(3) , 211-215.

Hamalik, 0. (2005). Teaching Planning Based on Approach. System. Jakarta: Bumi Aksara.

Hasan, S. (2008). Curriculum evaluation. Bandung: PT Remaja Rosdakarya.

Hayakawa, S. (1956). The Fully Functioning Personality. . ETC: A Review of General Semantics, 13(3), 169-181.

Kelley, E. (1967). The Fully Functioning Self. ETC: A Review of General Semantics, 24(4), 403-417.

Keyes, C. L. (2002). The mental health continuum: From languishing to flourishing in life. Journal of Health and Social Research, 43, 207-222.

Korsgaard, C. M. (2008). The constitution of agency: Essays on practical reason and moral psychology. Oxford: Oxford University Press.

Krapp, A., \& Prenzel, M. (2011). Research on Interest in Science: Theories, Methods and Findings. International Journal of Science Education, 33(1), 27-50. doi:10.1080/09500693.2010.518645

Krems, J., Kenrick, D., \& Neel, R. (2017). Individual Perceptions of Self-Actualization: What Functional Motives Are Linked to Fulfilling One's Full Potential? Personality and Social Psychology Bulletin, 43(9), 1337-1352.

Lee, T., Cheng, Y. C., \& Ko, J. (2018). Curriculum reform with a school-based approach: intellectual, structural and 
cultural challenges. School Leadership \& Management, 38:3, 278-301.

Levin, B. (2000). Putting Students at the Centre in Education Reform. Journal of Educational Change 1, 155-172.

Machali, I. (2014). 2013 Curriculum Changes in Welcoming a Golden Indonesia in 2045. Jurnal Pendidikan Islam, 3(1), 71-94 https://doi.org/10.14421/jpi.2014.31.71-94.

Malone, K. (2013). "The future lies in our hands": children as researchers and environmental change agents in designing a child-friendly neighbourhood. The International Journal of Justice and Sustainability, 18(3), 372-395. doi:10.1080/13549839.2012.719020

McCarthy, J., Whitebook, M., Ritchie, S., \& Frede, E. (2011). Early childhood education. Issues in Science and Technology, 27(2), 16-20.

Metroyadi \& Mardhiah, A. (2018). Efforts to Develop Children Fine Motor Skills Through Sticking Picture Properly By Using Combination of Explicit Instruction Model And Assignment Media Utilizing Natural Materials. J-K6EM, 1, 22.

Mittleman, W. (1991). Maslow's Study of Self-Actualization: A Reinterpretation. Journal of Humanistic Psychology, Vol. 31 (1), 114-135.

Mulyasa. (2016). Curriculum Development and Implementation 2013. Bandung: Remaja Rosdakarya.

Nawrotzki, K. (2009). Preface : New Perspectives on Preschooling: The Nation and the Transnational in Early Childhood Education. History of Education Quarterly, 49(2), 155.

Nurdin, \& Sibaweh. (2015). Pengelolaan Pendidikan dari Teori Menuju Implementasi. Jakarta: Raja Grafindo Persada.

Parlakian, R. (2003). Before the ABCs: Promoting school readiness in infants and toddlers. Washington, DC: Zero to Three.

Piaget, J. (1952). The origins of intelligence in children. New York: International University Press.

Purwanti, R., Suriansyah, A., Aslamiah, A., \& Dalle, J. (2018). Introducing language aspect (English) to early childhood through the combination of picture and picture model, talking stick model, flashcard media, and movement and song method in B1 group at Matahariku bilingual kindergarten Landasan Ulin Tengah . European Journal of Education Studies, 26-34.

Rogoff, B. (1990). Apprenticeship in thinking. New York: Oxford University Press.

Rosser, A. (2018). Beyond Access: Making Indonesia's Education System Work. Lowy Institute for International Policy.
Rowan, J. (2015). Self-actualization and individuation. Self \& Society, 43:3, 231-236.

Rozalena, \& Kristiawan. (2017). Pengelolaan Pembelajaran Paud Dalam Mengembangkan Potensi Anak Usia Din.

Rusman. (2012). Manajemen Kurikulum. Jakarta: Rajawali Pers.

Salasiah, Asniwati, \& Effendi, R. (2018). Instilling Character Values in Early Childhood in The Perspective of Curriculum and Parenting (Multi-Site Study in PAUD Islam Sabilal Muhtadin and PAUD Mawaddah, Banjarmasin, Indonesia). European Journal of Education Studies, 5 (7)., 41.

Sporlein, C., \& Schlueter, E. (2018). How education systems shape cross-national ethnic inequality in math competence scores: Moving beyond mean differences. PLOS ONE 13(3): e0193738.

Sterman, J. D. (2000). Business dynamics: systems thinking and modeling for a complex world. Boston: Irwin/McGraw-Hill.

Suhaimi \& Rinawati, Y. (2018). Management of Character Education Curriculum at Vocational High School 2 Kandangan. Advances in Social Science. Educational and Humanities Research, 272-274.

Sukriani, Huda A.Y, M., Arifin, I., \& Suriansyah, A. (2017). The Implementation of The Islamic Schools Resources Total Quality Management in Banjarmasin, Indonesia. Journal of Social Sciences (COES\&RJ-JSS), 6 (1), 125-138.

Suparlan. (2013). Manajemen Berbasis Sekolah Dari Teori Sampai dengan Praktik. Jakarta: Bumi Aksara.

Suriansyah, A. (2011). Landasan Pendidikan. Banjarmasin: Comdes.

Suriansyah, A., \& Aslamiah. (2011). Early Childhood Learning Strategies. Banjarmasin: Comdes.

Suyadi. (2011). Management of PAUD TPA-KB-TK / RA. Yogyakarta: Pustaka Pelajar.

Suyadi, \& Dahlia. (2017). Implementasi dan Inovasi Kurikulum 2013. Bandung: Remaja Rosdakarya .

Taines, C. (2012). Contents. Education and Urban Society, Vol. 44(3) , 247-273.

van den Akker, J. (2004). Curriculum Perspectives: An Introduction. In Curriculum Landscapes and Trends. Dordrecht: Springer.

Waterman, A. S. (2014). Self-Actualization. In Michalos A.C. (eds), Encyclopedia of Quality of Life and Well-Being Research. Dordrecht: Springer.

Whitehead, P. M. (2017). Goldstein's self-actualization: A biosemiotic view. The Humanistic Psychologist, 45(1), 7183. 
